\title{
Conservation, fiber digestibility, and nutritive value of corn harvested at 2 cutting heights and ensiled with fibrolytic enzymes, either alone or with a ferulic acid esterase-producing inoculant
}

\author{
J. P. Lynch, J. Baah, and K. A. Beauchemin ${ }^{1}$ \\ Agriculture and Agri-Food Canada, Lethbridge, AB, Canada T1J 4B1
}

\begin{abstract}
The aim of this study was to determine the effects of the use of a fibrolytic enzyme product, applied at ensiling either alone or in combination with a ferulic acid esterase-producing bacterial additive, on the chemical composition, conservation characteristics, and in vitro degradability of corn silage harvested at either conventional or high cutting height. Triplicate samples of corn were harvested to leave stubble of either a conventional (15 cm; NC) or high (45 cm; HC) height above ground. Sub-samples of chopped herbage were ensiled untreated or with a fibrolytic enzyme product containing xylanases and cellulases applied either alone (ENZ) or in combination with a ferulic acid esterase-producing silage inoculant (ENZ+FAEI). The fibrolytic enzyme treatment was applied at $2 \mathrm{~mL}$ of enzyme product/ $\mathrm{kg}$ of herbage dry matter (DM), and the inoculant was applied at $1.3 \times 10^{5} \mathrm{cfu} / \mathrm{g}$ of fresh herbage. Samples were packed into laboratory-scale silos, stored for 7,28 , or $70 \mathrm{~d}$, and analyzed for fermentation characteristics, and samples ensiled for $70 \mathrm{~d}$ were also analyzed for DM losses, chemical composition, and in vitro ruminal degradability. After $70 \mathrm{~d}$ of ensiling, the fermentation characteristics of corn silages were generally unaffected by cutting height, whereas the neutral detergent fiber, acid detergent fiber, and ash concentrations were lower and the starch concentration greater for silages made with crops harvested at $\mathrm{HC}$ compared with NC. After $70 \mathrm{~d}$ of ensiling, the acetic acid, ethanol concentrations, and the number of yeasts were greater, and the $\mathrm{pH}$ and neutral detergent fiber concentrations were lower, in silages produced using ENZ or ENZ+FAEI than the untreated silages, whereas ENZ+FAEI silages also incurred higher DM losses. No effect of additive treatment was observed on in vitro degradability indices after $48 \mathrm{~h}$ ruminal incubation. The use of a fibrolytic enzyme product, either alone or in combination with a ferulic acid esterase-producing inoculant, at ensiling
\end{abstract}

Received August 21, 2014.

Accepted October 8, 2014.

${ }^{1}$ Corresponding author: karen.beauchemin@agr.gc.ca did not improve corn silage fermentation or its nutritive value and resulted in some negative effects on these parameters. The effects of using a fibrolytic enzyme product at ensiling, either alone or in combination with a ferulic acid esterase-producing inoculant, did not differ between corn harvested at either NC or HC. Silage made from $\mathrm{HC}$ had a greater starch content and lower fiber content than NC silage, whereas cutting height did not affect the in vitro digestibility indices.

Key words: corn, fibrolytic enzyme, ferulic acid esterase, silage, additive

\section{INTRODUCTION}

Feed contributes a major input cost in animal production systems (Archer et al., 1999), and because grain prices are expected to remain high in coming years (Guyomard et al., 2013), the use of the forage components of ruminant diets needs to be maximized to improve the efficiency of livestock production systems. A primary limiting factor of forage utilization is fiber digestibility, with potentially under $600 \mathrm{~g} / \mathrm{kg}$ of fiber available for digestion by the ruminant animal (Van Soest, 1994).

Previous studies have observed the potential benefits of the use of feed additives containing fibrolytic enzymes, primarily consisting of xylanases and cellulases, to improve the fiber digestibility of corn silage (Colombatto et al., 2004; Phakachoed et al., 2013) and other forages (Pinos-Rodríguez et al., 2002; Eun and Beauchemin, 2008; Elghandour et al., 2013) when applied to the feed just before feeding. However, the application of fibrolytic enzymes before the ensilage of corn may facilitate an increased duration of interaction between the forage and the applied enzymes, potentially allowing for a greater impact on the nutritive value of the subsequent silage. Furthermore, silage inoculants that contain ferulic acid esterase-producing bacteria have the potential to improve the nutritive value of corn silage and other preserved feeds through the degradation of the linkages between lignin and cell wall carbohydrates (Kang et al., 2009; Addah et al., 2012). Therefore, the application of a silage inoculant containing ferulic acid esterase- 
producing bacteria to corn silage in combination with exogenous fibrolytic enzymes may increase the opportunity for the hydrolysis of cell wall carbohydrates and enable a greater improvement in forage nutritive value than silages produced using fibrolytic enzyme products alone.

Previous studies indicate that the effects of fibrolytic enzymes on the nutritive value of forages can be highly variable, depending on a range of factors including plant variety, harvest maturity, and forage chemical composition (Sheperd and Kung, 1996; Pinos-Rodríguez et al., 2002; Elghandour et al., 2013). Corn silage consists of 2 contrasting components, the high-starch ear and the high-fiber stover. Harvesting the crop at a higher cutting height can improve the nutritive value, and alter the chemical composition, of the resultant silage through increasing the proportion of cob and decreasing the proportion of stover in the harvested herbage (Neylon and Kung, 2003; Caetano et al., 2011). Therefore, the magnitude of the effects of fibrolytic enzyme additives on the nutritive value of corn, and its subsequent preservation, harvested at contrasting cutting heights may differ, due to the contrasting chemical composition of the ensiled forage. Furthermore, the degree of potential enzyme additive effects on these herbages may be enhanced by the use of a ferulic acid esterase inoculant, as the degradation of linkages between lignin and cell wall carbohydrates can increase the potential substrate for fibrolytic enzyme hydrolysis.

The objective of this study was to determine the effect of the use of a fibrolytic enzyme product produced for ruminants, applied at ensiling either alone or in combination with a ferulic acid esterase-producing bacterial additive, on the chemical composition, conservation characteristics, and degradability of corn silage harvested at either a conventional or high cutting height.

\section{MATERIALS AND METHODS}

Triplicate samples of corn harvested at either a conventional or high cutting height were allocated to 1 of 3 additive treatments and ensiled in laboratory-scale silos for 1 of 3 durations of ensiling ( $n=54$ samples). The silage fermentation profile of samples was investigated after each ensiling duration, whereas the estimated nutritive value, in vitro digestibility, and aerobic stability were assessed after only $70 \mathrm{~d}$ of ensiling.

\section{Forage Preparation}

Forage corn (Zea mays L.; hybrid: 39T67; Pioneer Hi-Bred Ltd., Chatham, ON, Canada) was grown on a commercial farm in Iron Springs, Alberta, Canada $\left(49^{\circ} 56^{\prime} \mathrm{N}, 6^{\circ} 39^{\prime} \mathrm{W}\right)$ in 2012 . On September 27 , for each of 2 plots (6 rows wide, $10 \mathrm{~m}$ long) allocated to either a normal cutting height (NC) or high cutting height (HC) in 3 replicate blocks, plots of corn were harvested at a target DM content of $300 \mathrm{~g}$ of fresh forage $/ \mathrm{kg}$ using a CLAAS Jaguar 960 corn harvester (CLAAS of America, Omaha, NE) fitted with a corn processor and chopped to approximately $0.9 \mathrm{~cm}$ theoretical chop length. Plots allocated to $\mathrm{NC}$ were harvested to leave 15 $\mathrm{cm}$ of stubble above ground, whereas plots allocated to $\mathrm{HC}$ were harvested to leave $45 \mathrm{~cm}$ of stubble. For each plot, chopped forage was transported to Lethbridge Research Centre, Alberta, within 30 min of harvest, placed on a shaded polyethylene sheet, and mixed thoroughly. Subsequently, three $20-\mathrm{kg}$ sub-samples were randomly taken, placed into pails, allocated to 1 of 3 additive treatments, and stored in a cool shaded area until ensiling.

\section{Ensilage}

Each $20-\mathrm{kg}$ sub-sample was placed onto a polyethylene sheet, sprayed with half of the allocated treatment, mixed thoroughly, sprayed with the remaining treatment, and mixed a second time. Three treatments were used for this study consisting of either an untreated control of distilled water or a commercial enzyme product (ENZ; 75:25 mix of Cellulase PLUS and Xylanase PLUS, respectively; Dyadic International, Jupiter, FL), applied alone or in combination with a ferulic acid esterase-producing inoculant (ENZ+FAEI; Pioneer 11GFT, Pioneer Hi-Bred Ltd.). The xylanase activity of ENZ was 7,527 xylose equivalents $\cdot \mathrm{min}^{-1} \cdot \mathrm{mL}^{-1}$ of enzyme, whereas the endoglucanase activity of ENZ was $420 \mu \mathrm{mol}$ of glucose equivalents $\cdot \mathrm{min}^{-1} \cdot \mathrm{mL}^{-1}$ of enzyme. The ENZ was applied at a rate of $2 \mathrm{~mL} / \mathrm{kg}$ of forage DM, whereas the bacterial inoculant was applied at 1 $\mathrm{g} / 1,000 \mathrm{~kg}$ of fresh forage to achieve $1.3 \times 10^{5} \mathrm{cfu} / \mathrm{g}$ of fresh forage for the ENZ+FAEI treatment. The inoculant contained a mixed bacterial culture of $1.0 \times$ $10^{11} \mathrm{cfu} / \mathrm{g}$ of Lactobacillus buchneri LN4017 (ATCC no. PTA-6138) that produced ferulic acid esterase, $2.0 \times$ $10^{10} \mathrm{cfu} / \mathrm{g}$ of Lactobacillus plantarum LP7109 (ATCC no. PTA-6139) and $1.0 \times 10^{10} \mathrm{cfu} / \mathrm{g}$ of Lactobacillus casei LC3200 (ATCC no. PTA-6135). All treatments were diluted in distilled water and applied using a total volume of $3 \mathrm{~mL} / \mathrm{kg}$ of fresh forage. Aseptic techniques were observed throughout ensiling to prevent contamination of samples. A 500-g sample of herbage was taken from each pile following treatment for microbial and chemical composition analyses.

Approximately $2.3 \mathrm{~kg}$ of herbage was packed into laboratory-scale polyvinyl chloride silos $(10.4 \mathrm{~cm}$ diameter $\times 35.6 \mathrm{~cm}$ height) using a hydraulic press to 
achieve a density of approximately $760 \mathrm{~kg}$ of fresh weight $/ \mathrm{m}^{3}$. Four laboratory silos were filled per $20-\mathrm{kg}$ pile, to evaluate samples after 7,28 , and $70 \mathrm{~d}$ of ensiling. Two laboratory silos were produced for $70 \mathrm{~d}$ of ensiling, which were pooled upon silo opening to create a larger sample for subsequent analyses. Therefore, 72 silos were produced in total. Silos were sealed airtight with rubber caps fastened by metal ties, whereas gas was released manually with a valve daily for the first $21 \mathrm{~d}$ of ensiling, and then weekly until gas pressure was no longer evident. Silos were weighed empty and filled, and stored at $20^{\circ} \mathrm{C}$ for the ensilage period. Following each silo's allocated ensiling duration, gas was released and silos were weighed before opening. Silage was thoroughly mixed and subsampled for microbial and chemical analyses.

\section{Chemical Analysis}

The DM content of samples was determined by drying at $55^{\circ} \mathrm{C}$ in a forced-air oven for $48 \mathrm{~h}$. Fresh-cut samples and samples ensiled for $70 \mathrm{~d}$ were lyophilized and ground through a 1-mm screen using a Wiley mill (Thomas Scientific, Swedesboro, NJ) for CP, starch, $\mathrm{NDF}, \mathrm{ADF}$, ash, and in vitro digestibility analyses. To determine $\mathrm{CP}(\mathrm{N} \times 6.25)$ and starch, ground feed samples were further ground to a fine powder using a ball grinder (Mixer Mill MM200, Retsch Inc., Newtown, PA). Nitrogen was quantified by flash combustion with gas chromatography and thermal conductivity detection (Nitrogen Analyzer 1500 series, Carlo Erba Instruments, Milan, Italy). Starch was determined after hydrolysis to $\alpha$-glucose polymers using amyloglucosidase (Megazyme Int. Ltd., Wicklow, Ireland) and 1,4 $\alpha$-D-glucan glucano-hydrolase (Brennfag Canada Inc., Toronto, ON, Canada) as described by Herrera-Saldana et al. (1990). Samples were read on a micro-plate reader (Appliskan, Thermo Electron Corporation, Vantaa, Finland) at a wavelength of $490 \mathrm{~nm}$. The NDF analysis was conducted according to the AOAC Official First Action method (Mertens, 2002) with the inclusion of heat-tolerant $\alpha$-amylase and sodium sulfite, and ADF was determined according to the AOAC International (2005; method 973.18). Both procedures were modified for use with the Ankom filter bag technique (Ankom Technology, Macedon, NY). The procedures were conducted sequentially and values are expressed on an ash-inclusive basis. Ash concentration was determined by complete combustion in a muffle furnace (Thermo Fisher Scientific, Rochford, UK) at $550^{\circ} \mathrm{C}$ for $5 \mathrm{~h}$. Buffering capacity was analyzed using the method of Playne and McDonald (1966).

Aqueous extracts were obtained from all ensiled samples by blending $15 \mathrm{~g}$ of fresh forage or silage with
$135 \mathrm{~mL}$ of distilled water in a Waring blender (Waring Commercial, Torrington, CT) for $30 \mathrm{~s}$ at full speed, and subsequently filtering through 2 layers of cheesecloth. The $\mathrm{pH}$ of the filtrate was determined using a Symphony $\mathrm{pH}$ meter (VWR, Mississauga, ON, Canada). For determination of VFA and ethanol, $1.5 \mathrm{~mL}$ of the supernatant was deproteinized with $0.3 \mathrm{~mL}$ of $25 \%$ (wt/ vol) metaphosphoric acid, combined with $0.2 \mathrm{~mL}$ of 0.1 $M$ crotonic acid as internal standard, and analyzed on a Hewlett Packard model 6890N gas-liquid chromatograph (Agilent Technologies Inc., Santa Clara, CA) with a ZB-FFAP fused silica capillary column $(30 \mathrm{~m}$ $\times 0.32 \mathrm{~mm}$ i.d. and $1.0 \mathrm{~m}$ film thickness; Phenomenex, Torrance, CA) and a flame ionization detector. For lactic acid determination, $400 \mu \mathrm{L}$ of the deproteinized sample was combined with $50 \mu \mathrm{L}$ of malonic acid $(5 \mathrm{mg} / \mathrm{mL})$ as an internal standard. Lactic acid was methylated with BF3-MeOH then quantified using the method of Kudo et al. (1987) on the same column and chromatograph as were used for VFA analysis. Total fermentation product was calculated as the sum of the VFA, lactic acid, and ethanol concentrations. To determine ammonia nitrogen, $1.6 \mathrm{~mL}$ of the supernatant was combined with $0.15 \mathrm{~mL}$ of $65 \%$ (wt/vol) trichloroacetic acid and analyzed by the salicylate method (Kempers and Zweers, 1986). The water-soluble carbohydrate (WSC; glucose equivalent) concentration was determined by the Nelson-Somogyi (Nelson, 1944) method using a Dynatech MRX micro-plate reader (Dynatech Laboratories Inc., Chantilly, VA) at $630 \mathrm{~nm}$.

\section{In Vitro Digestibility Analysis}

The in vitro digestibility procedure used was based on that described by Colombatto et al. (2003) and Eun et al. (2007). The procedure was conducted on 2 separate occasions (i.e., 2 replicate runs). Approximately $0.7 \mathrm{~g}$ of DM was weighed into filter bags (F57, Ankom Technology, Macedon, NY) that were previously washed with acetone, dried at $55^{\circ} \mathrm{C}$ for $24 \mathrm{~h}$ and weighed. Four replications of each sample were prepared for both incubation durations (24 and $48 \mathrm{~h}$ ) to reduce analytical error. Bags were heat-sealed, and a single bag was placed in a $125-\mathrm{mL}$ capacity serum vial (Wheaton Scientific, Millville, NJ). Ruminal fluid was obtained $2 \mathrm{~h}$ after feeding from 2 ruminally cannulated, nonlactating Angus cows fed a diet that consisted of barley silage $(600 \mathrm{~g} / \mathrm{kg}$ of DM), barley grain $(350 \mathrm{~g} / \mathrm{kg}$ of DM) and a vitamin-mineral supplement $(50 \mathrm{~g} / \mathrm{kg}$ of DM). Rumen fluid was obtained from various locations within the rumen, composited, and strained through 2 layers of cheesecloth under $\mathrm{CO}_{2}$ and was immediately transported to the laboratory, and kept at $39^{\circ} \mathrm{C}$ in a water bath while continually flushed with $\mathrm{CO}_{2}$. 
Anaerobic buffer medium ( $\mathrm{pH}$ 6.8) was prepared as described by Eun et al. (2007). Vials were flushed with $\mathrm{CO}_{2}$ before the addition of $48 \mathrm{~mL}$ of anaerobic buffer medium and $12 \mathrm{~mL}$ of rumen fluid. Vials were sealed and crimped with aluminum caps. Negative controls that contained buffer medium, rumen fluid, and an empty filter bag were also inoculated in 4 replications for each incubation duration. Inoculation of vials was complete within $1 \mathrm{~h}$ of rumen fluid collection and vials were incubated at $39^{\circ} \mathrm{C}$ for either 24 or $48 \mathrm{~h}$. Headspace gas production (GP) was measured after 3, 7, 19, 24, and $48 \mathrm{~h}$ of incubation. Measurements were made using a 23-gauge $(0.6 \mathrm{~mm})$ needle attached to a pressure transducer (model PX4200-015GI, Omega Engineering Inc., Laval, QC, Canada) connected to a visual display (Data Track, Christchurch, UK). Following measurement, the needle was left in place until gas pressure was completely released and then removed. Pressure values were corrected for values from negative controls and the amount of substrate DM incubated and subsequently used to generate volume estimates using the quadratic equation described by Mauricio et al. (1999). After each incubation duration, the appropriate vials were removed, placed in a water bath at $4^{\circ} \mathrm{C}$ to stop fermentation, and the filter bag was removed. Filter bags were hand washed under cold water until excess water ran clear, dried at $55^{\circ} \mathrm{C}$ for $24 \mathrm{~h}$, and weighed to determine DM degradability (DMD). The NDF and ADF digestibility (NDFD and ADFD, respectively) were determined by sequential analysis of the digested sample and filter bag using the methods described previously.

\section{Microbial Analysis}

Forage and silage samples were initially stored at $4^{\circ} \mathrm{C}$, and the isolation of microbes from the herbage commenced within $2 \mathrm{~h}$ of silo opening. Samples (10 g) were added to $90 \mathrm{~mL}$ of sterile $70 \mathrm{~m} M$ potassium phosphate buffer and homogenized for $60 \mathrm{~s}$ at $260 \mathrm{rpm}$ in a Stomacher 400 Laboratory Blender (Seward Medical Limited, London, UK), with a subsequent 1-mL aliquot serially diluted in potassium phosphate buffer. Media consisting of de Man, Rogosa, and Sharpe (Oxoid, Basingstoke, UK) and cycloheximide $(200 \mu \mathrm{g} / \mathrm{mL}$; SigmaAldrich, St. Louis, MO) were used for the enumeration of lactic acid bacteria (LAB), and nutrient agar (Difco, Detroit, MI) amended with cycloheximide (200 $\mu \mathrm{g} /$ $\mathrm{mL}$; Sigma-Aldrich) was used for enumeration of total aerobic culturable bacteria. The de Man, Rogosa, and Sharpe and nutrient agar plates were incubated at $37^{\circ} \mathrm{C}$ for $48 \mathrm{~h}$. Yeasts and molds were enumerated with Sabouraud's dextrose agar (Difco) amended with each of tetracycline and chloramphenicol $(100 \mu \mathrm{g} / \mathrm{mL}$; Sigma-
Aldrich) and were incubated at $20^{\circ} \mathrm{C}$ for $72 \mathrm{~h}$. Colonies were counted from plates containing a minimum of 30 and a maximum of 300 colonies.

\section{Experimental Design and Statistical Analysis}

Data to assess the nutritive value of samples taken before ensilage (i.e., d 0 samples) were subjected to a 1-way ANOVA, whereas as all other data were subjected to an analysis as a split-plot design using a model that accounted for cutting height $(\mathrm{n}=2)$ as the main plot, and additive treatment $(\mathrm{n}=3)$ as the sub-plot, their interactions, and replication. The ANOVA was performed separately for different ensiling durations (i.e., 7, 28, and $70 \mathrm{~d}$ ). All procedures were performed with the PROC MIXED procedure of the SAS statistical program (SAS Institute, 2002). Data from the in vitro digestibility assays were similarly analyzed with the inclusion of in vitro digestibility run as a random factor. Data for microbial population numbers were transformed by $\log _{10}$. The significance of specific treatment differences was calculated using the Fisher's least significant differences test. Treatment differences and trends were declared significant at $P \leq 0.05$ and $P \leq$ 0.10 , respectively.

\section{RESULTS}

\section{Pre-ensiling}

Crops harvested at HC had lower $(P<0.05$; Table 1) $\mathrm{ADF}$ and ash concentrations and total bacteria population numbers than crops harvested at NC. In addition, crops harvested at $\mathrm{HC}$ tended to have greater DM $(P=0.073)$ concentration and buffering capacity $(P=0.060)$, and lower NDF concentration $(P=0.062)$ compared with NC, whereas the starch, WSC, and CP concentrations and LAB, yeasts, and mold population numbers were unaffected $(P>0.05)$ by crop cutting height.

\section{Fermentation-Cutting Height}

After 7 and $28 \mathrm{~d}$ of ensiling, the lactic acid, acetic acid, ethanol, and total fermentation product concentrations, proportion of lactic acid in the total fermentation products, and LAB and yeast (only measured after $28 \mathrm{~d}$ of ensiling) population numbers were unaffected $(P>0.05)$ by corn cutting height (Tables 2 and 3 ), whereas silages made from crops harvested at $\mathrm{HC}$ tended to have a greater $(P<0.063) \mathrm{pH}$ value than crops harvested at NC. Propionic acid and butyric acid were below detectable values in all samples. 
Table 1. Chemical composition of corn, harvested at a normal (NC) or high (HC) cutting height at ensiling $(\mathrm{n}=3)$

\begin{tabular}{|c|c|c|c|c|}
\hline Item & $\mathrm{NC}$ & $\mathrm{HC}$ & SEM $^{1}$ & $P$-value \\
\hline $\mathrm{DM}$ ( $\mathrm{g} / \mathrm{kg}$ of fresh forage) & 318 & 361 & 12.4 & 0.073 \\
\hline Buffering capacity $(\mathrm{mEq} / \mathrm{kg}$ of $\mathrm{DM})$ & 115 & 135 & 5.4 & 0.060 \\
\hline $\mathrm{NDF}(\mathrm{g} / \mathrm{kg}$ of $\mathrm{DM})$ & 484 & 469 & 4.1 & 0.062 \\
\hline $\mathrm{ADF}(\mathrm{g} / \mathrm{kg}$ of $\mathrm{DM})$ & 257 & 233 & 4.2 & 0.017 \\
\hline Starch $(\mathrm{g} / \mathrm{kg}$ of $\mathrm{DM})$ & 280 & 313 & 21.9 & 0.200 \\
\hline Water-soluble carbohydrates $(\mathrm{g} / \mathrm{kg}$ of $\mathrm{DM})$ & 25 & 20 & 2.1 & 0.167 \\
\hline $\mathrm{CP}(\mathrm{g} / \mathrm{kg}$ of $\mathrm{DM})$ & 85 & 88 & 1.8 & 0.389 \\
\hline Ash (g/kg of DM) & 49 & 46 & 0.7 & 0.024 \\
\hline Lactic acid bacteria $\left(\log _{10} \mathrm{cfu}\right.$ of fresh forage $\left./ \mathrm{g}\right)$ & 6.3 & 6.1 & 0.28 & 0.403 \\
\hline Total culturable bacteria ( $\log _{10}$ cfu of fresh forage/g) & 7.65 & 7.39 & 0.065 & 0.049 \\
\hline Yeasts ( $\log _{10} \mathrm{cfu}$ of fresh forage/g) & 6.49 & 6.49 & 0.140 & 0.983 \\
\hline Molds ( $\log _{10} \mathrm{cfu}$ of fresh forage/g) & 5.25 & 5.36 & 0.219 & 0.624 \\
\hline
\end{tabular}

Similarly after $70 \mathrm{~d}$ of ensiling the fermentation characteristics of corn silages were generally unaffected $(P$ $>0.05$ ) by cutting height (Table 4$)$; however, the $\mathrm{pH}$ $(P=0.071)$ and yeast population numbers $(P=0.055)$ tended to be greater in $\mathrm{HC}$ silages than $\mathrm{NC}$.

\section{Fermentation-Additive Treatment}

After $7 \mathrm{~d}$ of ensiling, the fermentation characteristics of corn silages were generally unaffected $(P>0.05)$ by additive treatment; however, the LAB population numbers for $\mathrm{HC}$ silages treated with ENZ+FAEI were lower $(P<0.01)$ than other HC silages (Table 2$)$. When averaged across cutting height, the lactic acid and total fermentation product concentration of corn silages produced using ENZ+FAEI were greater $(P<0.05)$ than untreated silages after $28 \mathrm{~d}$ of ensiling, whereas the acetic acid and ethanol concentrations and yeast population numbers were greater $(P<0.05)$ for silage made using either ENZ alone or ENZ+FAEI when compared with untreated silages (Table 3 ). In addition, the proportion of lactic acid in the total fermentation products was lower $(P<0.05)$ in silages produced using ENZ alone compared with the other silages after $28 \mathrm{~d}$ of ensiling, when averaged across cutting heights. The $\mathrm{pH}$ of corn silages produced with ENZ or ENZ+FAEI was greater $(P=0.001)$ than untreated silages, whereas the yeast population numbers of corn silages produced with ENZ or ENZ+FAEI were higher $(P>0.001)$ than untreated silages, after $28 \mathrm{~d}$ of ensiling.

Table 2. Fermentation characteristics after $7 \mathrm{~d}$ of ensilage for corn silage harvested at a normal (NC) or high (HC) cutting height and treated with a fibrolytic enzyme (ENZ) and ferulic acid esterase-producing inoculant (FAEI)

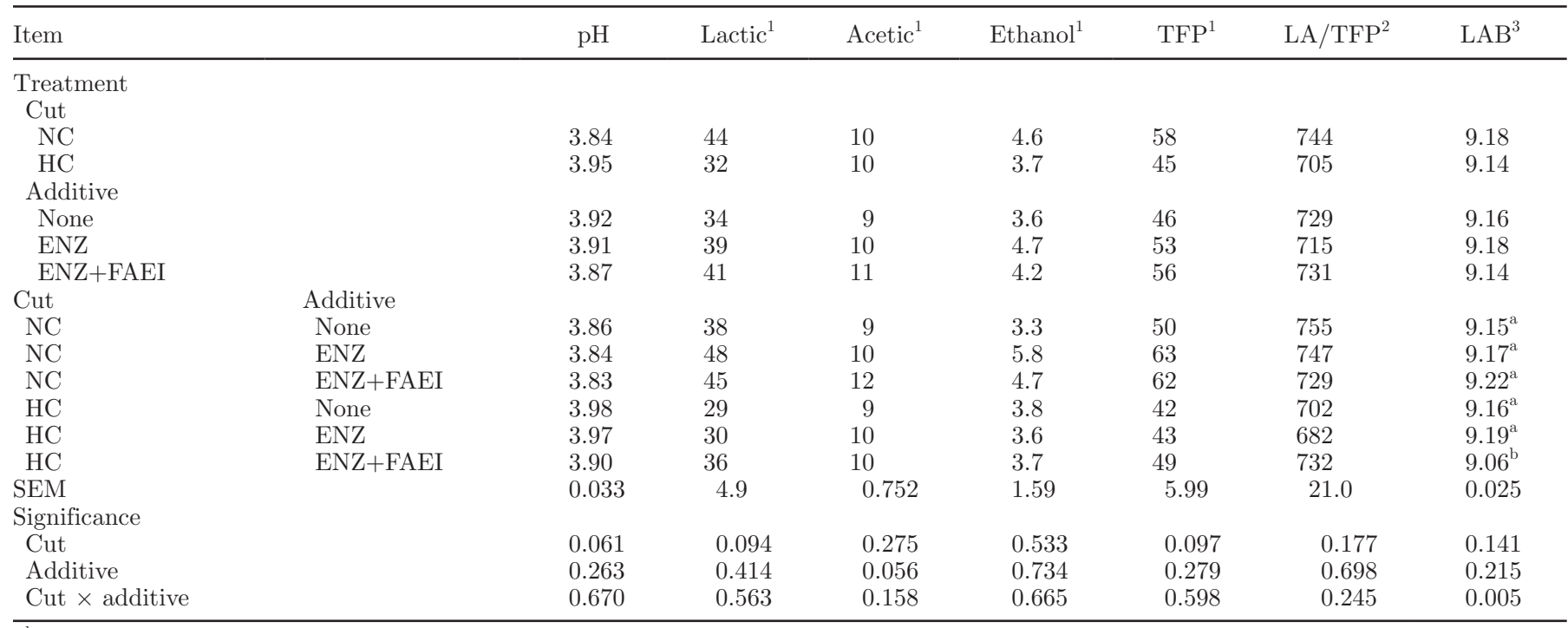

\footnotetext{
${ }^{\mathrm{a}, \mathrm{b}}$ Means $(\mathrm{n}=3)$ within a column and category with different superscripts differ $(P<0.05)$.

${ }^{1} \mathrm{~g} / \mathrm{kg}$ of DM; TFP $=$ total fermentation products (lactic acid + volatile fatty acids + ethanol).

${ }^{2} \mathrm{~g}$ of lactic acid/g of total fermentation products.

${ }^{3} \mathrm{LAB}=$ lactic acid bacteria, $\log _{10}(\mathrm{cfu} / \mathrm{g}$ of wet silage $)$.
} 
Table 3. Fermentation characteristics after $28 \mathrm{~d}$ of ensilage for corn silage harvested at a normal (NC) or high (HC) cutting height and treated with a fibrolytic enzyme (ENZ) and ferulic acid esterase-producing inoculant (FAEI)

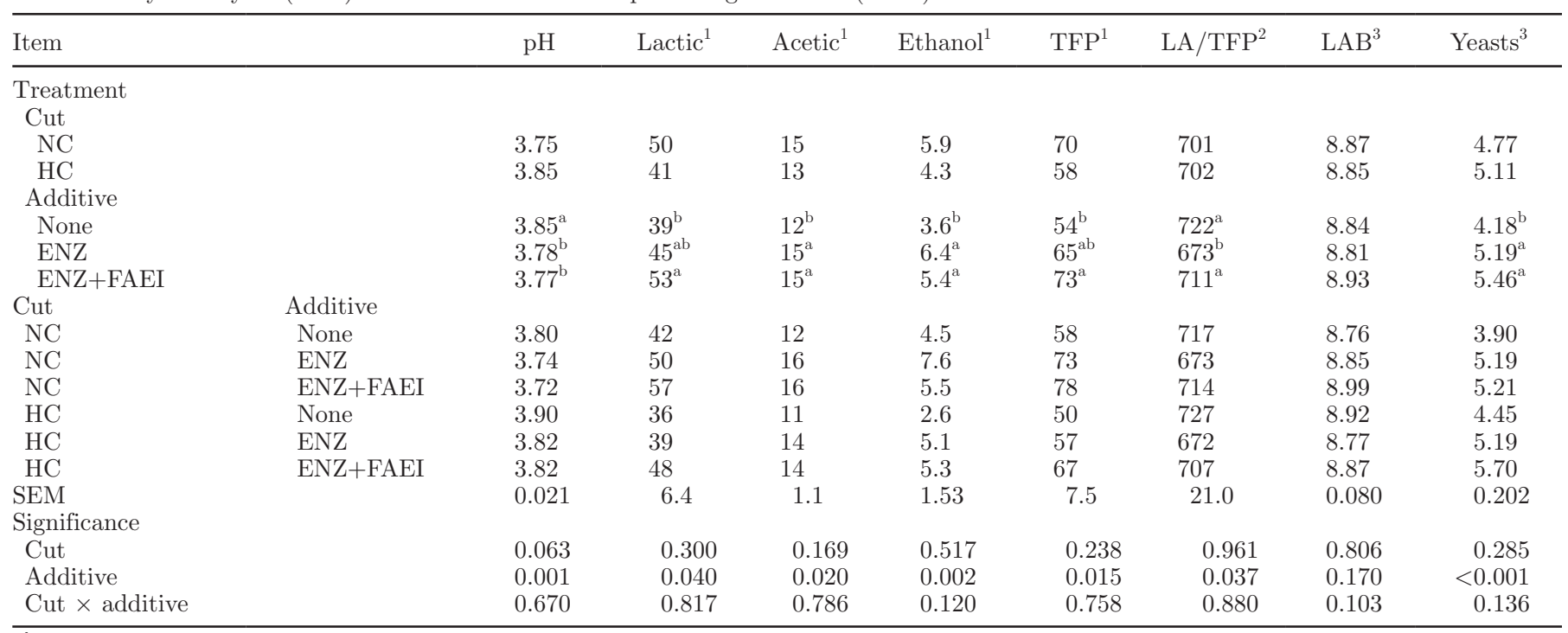

${ }^{\mathrm{a}, \mathrm{b}}$ Means $(\mathrm{n}=3)$ within a column with different superscripts differ $(P<0.05)$.

${ }^{1} \mathrm{~g} / \mathrm{kg}$ of DM; TFP $=$ total fermentation products (lactic acid + volatile fatty acids + ethanol).

${ }^{2} \mathrm{~g}$ of lactic acid/g of total fermentation products.

${ }^{3} \mathrm{LAB}=$ lactic acid bacteria, $\log _{10}(\mathrm{cfu} / \mathrm{g}$ of wet silage $)$.

After $70 \mathrm{~d}$ of ensiling, the acetic acid and ethanol concentrations and yeast population numbers were greater $(P<0.05)$ and the $\mathrm{pH}$ was lower $(P<0.01)$ in silages produced using either ENZ or ENZ+FAEI, when averaged across cutting height (Table 4). In addition, the total fermentation product concentration and DM losses of silages produced using ENZ+FAEI was greater $(P<0.05)$ than untreated silages, when

Table 4. Fermentation characteristics after $70 \mathrm{~d}$ of ensilage for corn silage harvested at a normal (NC) or high (HC) cutting height and treated with a fibrolytic enzyme (ENZ) and ferulic acid esterase-producing inoculant (FAEI)

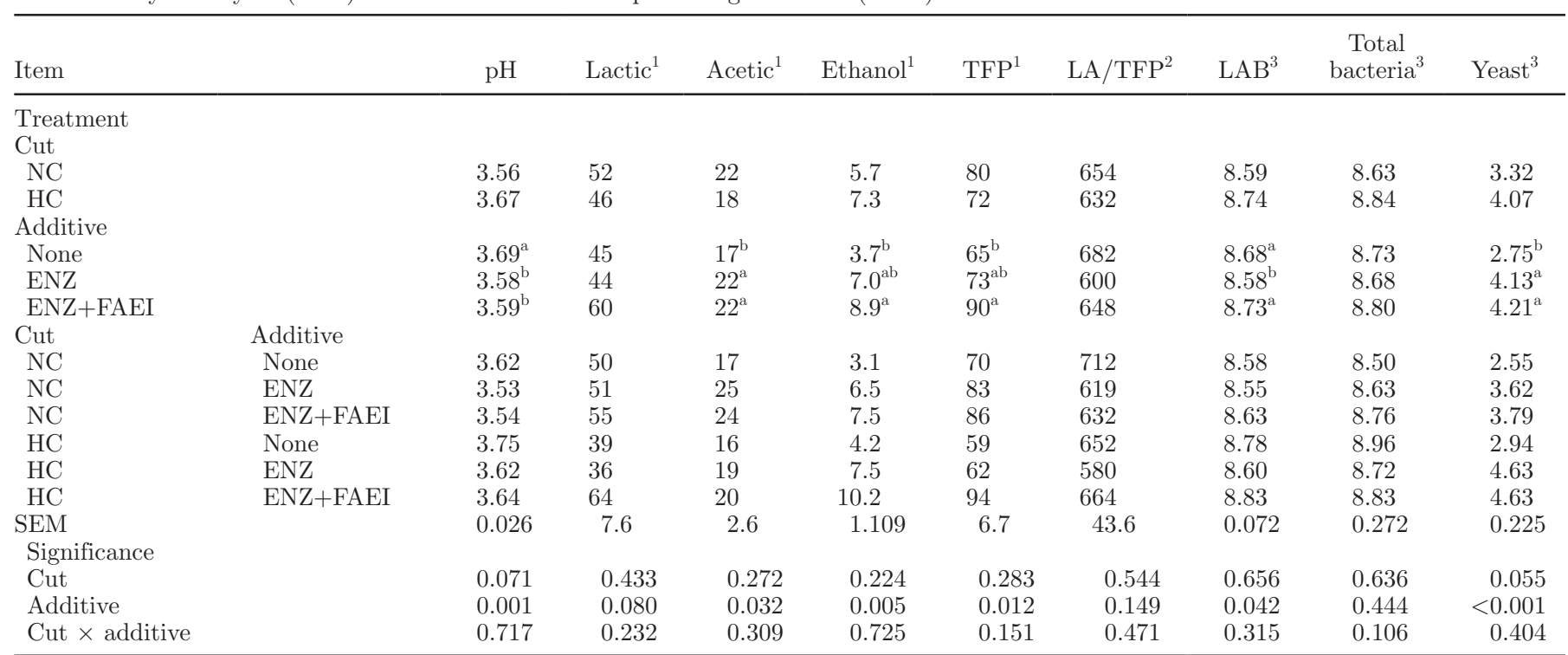

${ }_{\mathrm{a}, \mathrm{b}}$ Means $(\mathrm{n}=3)$ within a column with different superscripts differ $(P<0.05)$

${ }^{1} \mathrm{~g} / \mathrm{kg}$ of DM; TFP $=$ total fermentation products (lactic acid + volatile fatty acids + ethanol).

${ }^{2} \mathrm{~g}$ of lactic acid/g of total fermentation products.

${ }^{3} \mathrm{LAB}=$ lactic acid bacteria, $\log _{10}(\mathrm{cfu} / \mathrm{g}$ of wet silage $)$. 
Table 5. Chemical composition, and DM losses after $70 \mathrm{~d}$ of ensilage for corn silage harvested at a normal (NC) or high (HC) cutting height and treated with a fibrolytic enzyme (ENZ) and ferulic acid esterase-producing inoculant (FAEI)

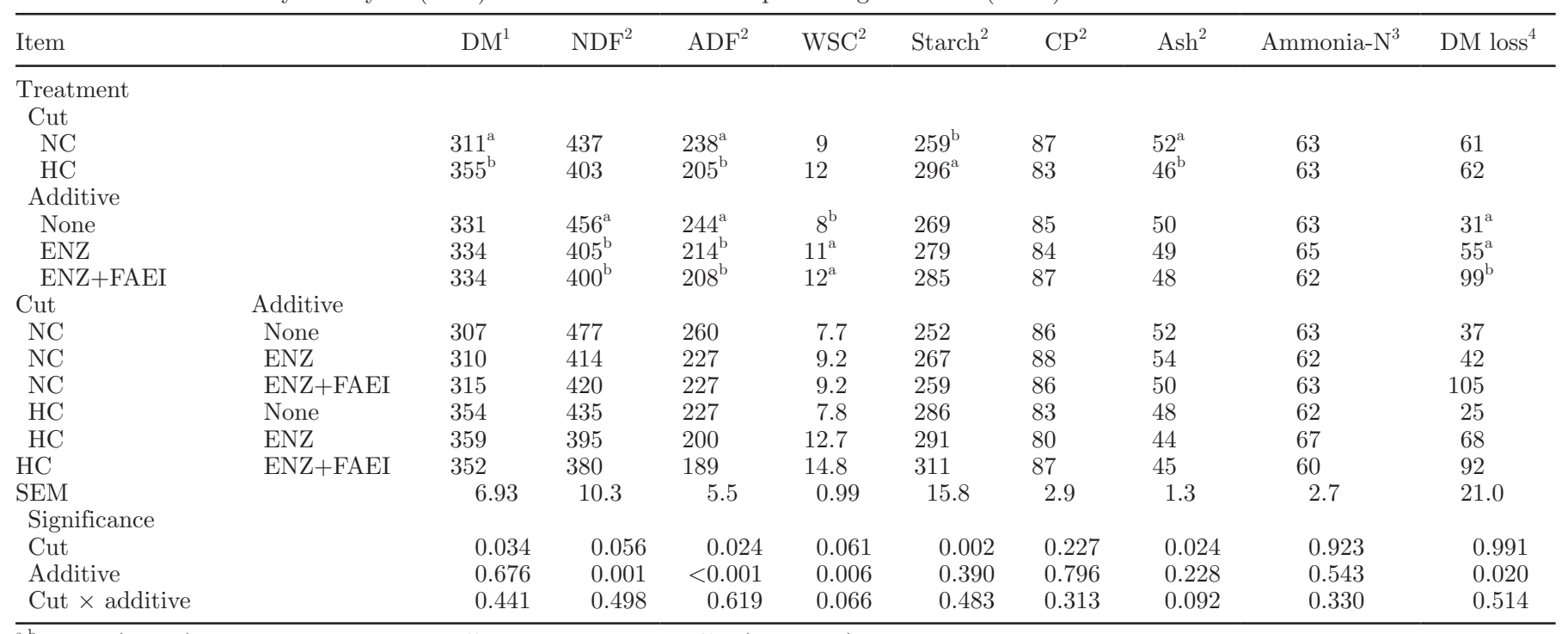

${ }_{\mathrm{a}, \mathrm{b}}$ Means $(\mathrm{n}=3)$ within a column with different superscripts differ $(P<0.05)$.

${ }^{1} \mathrm{~g} / \mathrm{kg}$ of fresh forage.

${ }^{2} \mathrm{~g} / \mathrm{kg}$ of DM.

${ }^{3} \mathrm{~g} / \mathrm{kg}$ of $\mathrm{CP}$.

${ }^{4} \mathrm{~g}$ of DM disappearance/kg of DM ensiled.

averaged across cutting heights. The LAB population numbers of silages produced using ENZ+FAEI were greater $(P<0.05)$ than silages made using ENZ alone, when averaged across cutting heights. The lactic acid concentration, proportion of lactic acid in total fermentation products and total bacteria population numbers were unaffected $(P>0.05)$ by additive treatment.

\section{Chemical Composition and In Vitro Digestibility- Cutting Height (70 d of Ensiling)}

The ADF and ash concentrations were lower $(P<$ $0.05)$ and the DM and starch concentration greater $(P$ $<0.05)$ for silages made with crops harvested at $\mathrm{HC}$ compared with NC (Table 5). Furthermore, the NDF concentration tended to be greater $(P=0.056)$ in silages made with crops harvested at $\mathrm{NC}$ than at $\mathrm{HC}$. The WSC concentration and ammonia-N proportion of corn silages were unaffected $(P>0.05)$ by cutting height. The in vitro DMD and gas production of corn silages were unaffected $(P>0.05$; Table 6$)$ by cutting height after all incubation periods. After $24 \mathrm{~h}$ of in vitro ruminal incubation, the ADFD was greater $(P<$ $0.05)$ and NDFD tended to be greater $(P=0.071)$ for silages made from crops harvested at $\mathrm{NC}$, compared with silages made from HC. However, after $48 \mathrm{~h}$ of in vitro ruminal incubation, NDFD and ADFD of corn silages were not affected $(P>0.05)$ by cutting height.

\section{Chemical Composition and In Vitro Digestibility- Additive (70 $d$ of Ensiling)}

The NDF and ADF concentrations of corn silages made using either ENZ alone or ENZ+FAEI were lower $(P<0.001)$ than untreated silages, whereas the WSC concentration was greater $(P<0.01)$ for both ENZtreated silages than untreated silages, when averaged across cutting heights. The starch, CP, and ash concentration and ammonia- $\mathrm{N}$ proportion were unaffected $(P$ $>0.05)$ by additive treatment.

The DMD of corn silage made using crops harvested at $\mathrm{HC}$ and ensiled with ENZ alone was lower $(P<0.001)$ than other HC silages, after $24 \mathrm{~h}$ in vitro incubation, whereas no effect of additive treatment was observed on silages after $48 \mathrm{~h}$ of in vitro incubation. When averaged across cutting heights, corn silages made using ENZ alone had a lower $(P<0.05)$ in vitro NDFD and ADFD than other silages after $24 \mathrm{~h}$ digestion, whereas no effect of additive treatment $(P>0.05)$ was observed on silages after $48 \mathrm{~h}$ of in vitro incubation.

\section{DISCUSSION}

\section{Cutting Height}

The DM, NDF, and CP concentrations of corn before ensiling was indicative of a crop harvested at a normal silage maturity (NRC, 2001) and was within the 
Table 6. In vitro digestibility indices after $70 \mathrm{~d}$ of ensilage for corn silage harvested at a normal (NC) or high (HC) cutting height and treated with a fibrolytic enzyme (ENZ) and ferulic acid esterase-producing inoculant (FAEI)

\begin{tabular}{|c|c|c|c|c|c|c|c|c|c|c|c|c|}
\hline \multirow[b]{2}{*}{ Item } & & \multicolumn{2}{|c|}{$\mathrm{DMD}^{1}$} & \multicolumn{2}{|c|}{$\mathrm{NDFD}^{2}$} & \multicolumn{2}{|c|}{$\mathrm{ADFD}^{3}$} & \multicolumn{5}{|c|}{ Gas production ${ }^{4}$} \\
\hline & & $24 \mathrm{~h}$ & $48 \mathrm{~h}$ & $24 \mathrm{~h}$ & $48 \mathrm{~h}$ & $24 \mathrm{~h}$ & $48 \mathrm{~h}$ & $3 \mathrm{~h}$ & $7 \mathrm{~h}$ & $19 \mathrm{~h}$ & $24 \mathrm{~h}$ & $48 \mathrm{~h}$ \\
\hline \multicolumn{13}{|l|}{ Treatment } \\
\hline \multicolumn{13}{|l|}{ Cut } \\
\hline $\mathrm{NC}$ & & 595 & 691 & 193 & 343 & 155 & 275 & 13 & 40 & 111 & 139 & 178 \\
\hline $\mathrm{HC}$ & & 590 & 688 & 171 & 327 & 127 & 262 & 14 & 43 & 114 & 144 & 184 \\
\hline \multicolumn{13}{|l|}{ Additive } \\
\hline None & & $600^{\mathrm{a}}$ & 689 & $201^{\mathrm{a}}$ & 340 & $160^{\mathrm{a}}$ & 276 & $13^{\mathrm{b}}$ & $40^{\mathrm{b}}$ & 112 & 141 & 183 \\
\hline ENZ & & $582^{\mathrm{b}}$ & 678 & $159^{\mathrm{b}}$ & 319 & $118^{\mathrm{b}}$ & 255 & $13^{\mathrm{b}}$ & $40^{\mathrm{b}}$ & 110 & 139 & 176 \\
\hline $\mathrm{ENZ}+\mathrm{FAEI}$ & & $596^{\mathrm{ab}}$ & 701 & $187^{\mathrm{a}}$ & 347 & $145^{\mathrm{a}}$ & 275 & $15^{\mathrm{a}}$ & $47^{\mathrm{a}}$ & 115 & 145 & 185 \\
\hline Cut & Additive & & & & & & & & & & & \\
\hline $\mathrm{NC}$ & None & $596^{\mathrm{a}}$ & 686 & 204 & 346 & 174 & 284 & 12 & 38 & 111 & 139 & 177 \\
\hline $\mathrm{NC}$ & ENZ & $602^{\mathrm{a}}$ & 693 & 180 & 335 & 134 & 268 & 12 & 39 & 110 & 139 & 179 \\
\hline $\mathrm{NC}$ & ENZ+FAEI & $586^{\mathrm{a}}$ & 694 & 196 & 347 & 156 & 273 & 15 & 44 & 111 & 140 & 179 \\
\hline $\mathrm{HC}$ & None & $604^{\mathrm{a}}$ & 692 & 197 & 333 & 145 & 267 & 13 & 41 & 113 & 143 & 189 \\
\hline $\mathrm{HC}$ & ENZ & $561^{\mathrm{b}}$ & 663 & 138 & 303 & 102 & 242 & 13 & 40 & 110 & 138 & 173 \\
\hline $\mathrm{HC}$ & ENZ+FAEI & $605^{\mathrm{a}}$ & 708 & 177 & 346 & 133 & 276 & 15 & 49 & 119 & 150 & 190 \\
\hline SEM & & 15.5 & 11.2 & 14.6 & 23.7 & 12.8 & 25.4 & 0.9 & 3.0 & 4.5 & 4.7 & 5.5 \\
\hline \multicolumn{13}{|l|}{ Significance } \\
\hline Cut & & 0.587 & 0.735 & 0.071 & 0.399 & 0.033 & 0.433 & 0.339 & 0.197 & 0.484 & 0.311 & 0.231 \\
\hline Additive & & 0.020 & 0.147 & 0.002 & 0.328 & $<0.001$ & 0.386 & 0.004 & 0.009 & 0.343 & 0.322 & 0.253 \\
\hline Cut $\times$ additive & & $<0.001$ & 0.128 & 0.233 & 0.698 & 0.899 & 0.693 & 0.869 & 0.689 & 0.564 & 0.502 & 0.179 \\
\hline
\end{tabular}

${ }_{\mathrm{a}, \mathrm{b}}$ Means $(\mathrm{n}=3)$ within a column with different superscripts differ $(P<0.05)$.

${ }^{1} \mathrm{~g} / \mathrm{kg}$ of DM; DMD = in vitro DM digestibility.

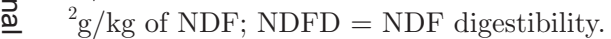

을 ${ }^{3} \mathrm{~g} / \mathrm{kg}$ of $\mathrm{ADF} ; \mathrm{ADFD}=\mathrm{ADF}$ digestibility.

${ }^{4} \mathrm{~mL} / \mathrm{g}$ of $\mathrm{DM}$ 
range of NDF concentrations (426 to $510 \mathrm{~g} / \mathrm{kg}$ of DM) reported by previous studies that investigated the use of fibrolytic enzymes or ferulic acid esterase-producing inoculants (Sheperd and Kung, 1996; Colombatto et al., 2004; Kang et al., 2009).

The higher pre-ensilage concentrations of NDF and $\mathrm{ADF}$ and the lower DM concentration for corn samples harvested at $\mathrm{NC}$ compared with herbage harvested at $\mathrm{HC}$ reflected the higher proportion of the more fibrous crop component, corn stover, in the harvested herbage. This is in accord with similar studies by Lewis et al. (2004) and Caetano et al. (2011) who reported increased concentrations of cell wall carbohydrates for corn hybrids harvested at a range of high cutting heights (46-95 cm from ground), when compared with conventional cutting heights (5-15 $\mathrm{cm}$ from ground). The lack of effect of cutting height on the starch concentration of corn was in disagreement with Lewis et al. (2004), who reported greater starch concentrations in corn harvested at $46 \mathrm{~cm}$ compared with crops harvested at $15 \mathrm{~cm}$. The greater buffering capacity of samples harvested at $\mathrm{HC}$ in the present study is in contrast to Caetano et al. (2011), who reported that harvesting corn at a greater cutting height reduced the herbage buffering capacity. Furthermore, Lynch et al. (2012) found that the stover component had a greater buffering capacity value when compared with the ear, and thus, the increased buffering capacity of corn samples harvested at $\mathrm{HC}$ in the present study was not expected.

The effects of cutting height on the chemical composition of untreated corn after $70 \mathrm{~d}$ of ensiling were similar to the pre-ensiled herbage. This is a reflection on the general lack of effect of cutting height on the silage fermentation of corn samples, in accordance with Neylon and Kung (2003), who reported no difference in the silage fermentations of corn harvested at either 12.7 or $45.7 \mathrm{~cm}$. The tendency for lower $\mathrm{pH}$ of silages harvested at $\mathrm{NC}$ compared with $\mathrm{HC}$ was likely due to the lower buffering capacity of these herbages, as forages with low buffering capacity require lesser volumes of lactic acid to achieve a unit reduction in $\mathrm{pH}$ (Greenhill, 1964). The effects of cutting height on the indices of in vitro degradability were also minor, with the exception of increased NDFD and ADFD for NC silages after 24 $\mathrm{h}$ incubation. Despite this, no effects of cutting height were observed for any degradability indices after $48 \mathrm{~h}$ of incubation. These results are in disagreement with previous studies by Lewis et al. (2004) and Caetano et al. (2011) who found greater in vitro DMD for samples harvested at higher cutting heights than conventional, whereas Neylon and Kung (2003) and Caetano et al. (2011) also reported greater NDFD for samples harvested at increased cutting heights.

\section{Additive Treatments}

Despite a lack of effect of fibrolytic enzyme treatment after $7 \mathrm{~d}$ of ensilage, samples ensiled for 28 or $70 \mathrm{~d}$ with ENZ or ENZ+FAEI had a lower $\mathrm{pH}$ and greater acetic acid concentrations, whereas samples ensiled using ENZ+FAEI underwent a more extensive fermentation and had a greater ethanol concentration, compared with untreated silages. However, the magnitudes of differences were minor, with no differences in ammonia- $\mathrm{N}$ proportions observed between fibrolytic enzyme treatments. Similarly, Stokes and Chen (1994) and Sheperd and Kung (1996) found only minor effects of fibrolytic enzyme use on corn silage fermentation. However, silages produced using either ENZ or ENZ+FAEI and stored for $70 \mathrm{~d}$ had greater yeast population numbers, which may increase the inefficient production of ethanol and the susceptibility of the silage to aerobic deterioration upon exposure to air (Woolford, 1990). Similarly, previous studies on the production of corn silage using fibrolytic enzyme mixtures have reported increases in yeast numbers in enzyme-treated silages (Spoelstra et al., 1992; Sheperd and Kung, 1996). Despite increased DM losses, the silage fermentation of samples produced using a ferulic acid esterase-producing inoculant in addition to the fibrolytic enzyme product did not generally differ from silages produced using the enzyme product alone, with the exceptions of greater concentrations of ethanol and total fermentation products after $70 \mathrm{~d}$, indicating that the inoculated lactic acid bacteria did not dominate the epiphytic microbial populations during the silage fermentation. The greater ethanol concentrations may have been a product of yeast fermentation, which also produces $\mathrm{CO}_{2}$ and therefore partially contributed to the increased DM losses (Buxton et al., 2003). It should be noted that the use of the FAEI inoculant together with enzymes for preservation of corn was beyond the recommended use of the product by the manufacturer.

The reduced NDF and ADF concentrations of silages produced using ENZ or ENZ+FAEI compared with untreated silages likely reflects increased hydrolysis of cell-wall carbohydrates by the added fibrolytic enzymes. These observations are in accord with similar studies by Chen et al. (1994) and Sheperd and Kung (1996) that ensiled corn with a fibrolytic enzyme mixture and reported reductions in the concentrations of cell wall carbohydrates. Despite this, the lack of an effect of additive treatment on the in vitro DM or fiber degradability after $48 \mathrm{~h}$ incubation indicates that the use of fibrolytic enzymes did not improve the nutritive value of the corn silage. Similarly, previous studies that have ensiled corn with fibrolytic enzyme additives 
have reported inconsistent effects on silage digestibility (Chen et al., 1994; Sheperd and Kung, 1996; Kung et al., 2000). However, it should be noted that improvements in fiber digestibility of corn silages treated with fibrolytic enzymes before in vitro digestion have also been reported (Colombatto et al., 2004; Phakachoed et al., 2013). The reduced in vitro NDFD and ADFD after $24 \mathrm{~h}$ of incubation of silages produced using ENZ, compared with untreated silages, indicates that the more easily digestible components of NDF were likely hydrolyzed during the ensiling of these samples. Despite a lack of difference in the in vitro NDFD and ADFD of untreated corn silages and silages produced using ENZ+FAEI, the greater NDFD and ADFD after $24 \mathrm{~h}$ of incubation for silages produced using ENZ+FAEI compared with silages produced using ENZ alone indicates that the cell wall carbohydrates were more easily digestible in silages produced with both the fibrolytic enzyme and the ferulic acid esterase-producing inoculant. A previous study by Kang et al. (2009) that used a similar inoculant reported the ability of ferulic acid esterase-producing bacteria to increase the digestibility of cell wall carbohydrates of corn silage. Therefore, despite a minimal effect on the fermentation dynamics of corn silages indicating that the inoculated organisms in silages made with ENZ+FAEI did not dominate the epiphytic microbial populations, the use of the FAEI had a significant impact on fiber digestibility and DM losses, likely through increasing the availability of substrate for microbial degradation.

\section{CONCLUSIONS}

The use of a fibrolytic enzyme product at ensiling did not improve corn silage fermentation or its nutritive value and resulted in some negative effects on these parameters. The use of a ferulic acid esteraseproducing inoculant in combination with a fibrolytic enzyme product did not improve the silage fermentation or nutritive value of corn silage and increased DM losses during preservation, compared with untreated silages, but did reduce the negative effects of fibrolytic enzyme use on fiber digestibility. The effects of using a fibrolytic enzyme product at ensiling, either alone or in combination with a ferulic acid esterase-producing inoculant, did not differ between corn harvested at either a conventional $(15 \mathrm{~cm})$ or high $(45 \mathrm{~cm})$ cutting height. Silage produced from corn harvested at a high cutting height had a greater starch content and lower fiber content than conventional cut silage, whereas cutting height did not affect the in vitro digestibility indices of corn silages.

\section{ACKNOWLEDGMENTS}

Financial support for this study was provided by the Alberta Livestock and Meat Agency Ltd. (Project LOI 2012CO13R). The authors thank the staff of Agriculture and Agri-Food Canada, Lethbridge, especially L. Jin, Z. Matic, C. Barkley, B. Farr, F. Van Herk, B. Baker, A. David, L. Duniere, and W. Addah, for their invaluable assistance on this project and Dyadic International Ltd. (Jupiter, FL) for providing samples of their commercial products for use in the study. The inoculant was purchased commercially, with its use approved by Pioneer Hi-Bred Ltd. (Johnston, IA).

\section{REFERENCES}

Addah, W., J. Baah, E. K. Okine, and T. A. McAllister. 2012. A thirdgeneration esterase inoculant alters fermentation pattern and improves aerobic stability of barley silage and the efficiency of body weight gain of growing feedlot cattle. J. Anim. Sci. 90:1541-1552.

AOAC International. 2005. Official Methods of Analysis. 18th ed. AOAC International, Gaithersburg, MD.

Archer, J. A., E. C. Richardson, R. M. Herd, and P. F. Arthur. 1999. Potential for selection to improve efficiency of feed use in beef cattle: A review. Aust. J. Agric. Res. 50:147-162.

Buxton, D. R., R. E. Muck, and J. H. Harrison. 2003. Silage Science and Technology. American Society of Agronomy Inc., Madison, WI.

Caetano, H., M. D. S. d. Oliveira, J. E. d. Freitas Júnior, A. C. d. Rêgo, F. P. Rennó, and M. V. d. Carvalho. 2011. Evaluation of corn cultivars harvested at two cutting heights for ensilage. $\mathrm{R}$. Bras. Zootec. 40:12-19.

Chen, J., M. R. Stokes, and C. R. Wallace. 1994. Effects of enzymeinoculant systems on preservation and nutritive value of haycrop and corn silages. J. Dairy Sci. 77:501-512.

Colombatto, D., F. L. Mould, M. K. Bhat, and E. Owen. 2003. Use of fibrolytic enzymes to improve the nutritive value of ruminant diets: A biochemical and in vitro rumen degradation assessment. Anim. Feed Sci. Technol. 107:201-209.

Colombatto, D., F. L. Mould, M. K. Bhat, R. H. Phipps, and E. Owen. 2004. In vitro evaluation of fibrolytic enzymes as additives for maize (Zea mays L.) silage: II. Effects on rate of acidification, fibre degradation during ensiling and rumen fermentation. Anim. Feed Sci. Technol. 111:129-143.

Elghandour, M. M. Y., A. Z. M. Salem, M. Gonzalez-Ronquillo, J. L. Bórquez, H. M. Gado, N. E. Odongo, and C. G. Peñuelas. 2013. Effects of exogenous enzymes on in vitro gas production kinetics and ruminal fermentation of four fibrous feeds. Anim. Feed Sci. Technol. 179:46-53.

Eun, J. S., and K. A. Beauchemin. 2008. Relationship between enzymic activities and in vitro degradation of alfalfa hay and corn silage. Anim. Feed Sci. Technol. 145:53-67.

Eun, J. S., K. A. Beauchemin, and H. Schulze. 2007. Use of an in vitro fermentation bioassay to evaluate improvements in degradation of alfalfa hay due to exogenous feed enzymes. Anim. Feed Sci. Technol. 135:315-328.

Greenhill, W. L. 1964. The buffering capacity of pasture plants with special reference to ensilage. Aust. J. Agric. Res. 15:511-519.

Guyomard, H., S. Manceron, and J.-L. Peyraud. 2013. Trade in feed grains, animals, and animal products: Current trends, future prospects, and main issues. Anim. Front. 3:14-18.

Herrera-Saldana, R. E., J. T. Huber, and M. H. Poore. 1990. Dry matter, crude protein, and starch degradability of five cereal grains. J. Dairy Sci. 73:2386-2393. 
Kang, T. W., A. T. Adesogan, S. C. Kim, and S. S. Lee. 2009. Effects of an esterase-producing inoculant on fermentation, aerobic stability, and neutral detergent fiber digestibility of corn silage. J. Dairy Sci. 92:732-738.

Kempers, A. J., and A. Zweers. 1986. Ammonium determination in soil extracts by the salicylate method. Commun. Soil Sci. Plan. 17:715-723.

Kudo, H., K. J. Cheng, and J. W. Costerton. 1987. Interactions between Treponema bryantii and cellulolytic bacteria in the in vitro degradation of straw cellulose. Can. J. Microbiol. 33:244-248.

Kung, L. Jr., R. J. Treacher, G. A. Nauman, A. M. Smagala, K. M. Endres, and M. A. Cohen. 2000. The effect of treating forages with fibrolytic enzymes on its nutritive value and lactation performance of dairy cows. J. Dairy Sci. 83:115-122.

Lewis, A. L., W. J. Cox, and J. H. Cherney. 2004. Hybrid, maturity, and cutting height Interactions on corn forage yield and quality. Agron. J. 96:267-274.

Lynch, J. P., P. O'Kiely, and E. M. Doyle. 2012. Yield, quality and ensilage characteristics of whole-crop maize and of the cob and stover components: Harvest date and hybrid effects. Grass Forage Sci. $67: 472-487$.

Mauricio, R. M., F. L. Mould, M. S. Dhanoa, E. Owen, K. S. Channa, and M. K. Theodorou. 1999. A semi-automated in vitro gas production technique for ruminant feedstuff evaluation. Anim. Feed Sci. Technol. 79:321-330.

Mertens, D. R. 2002. Gravimetric determination of amylase-treated neutral detergent fiber in feeds with refluxing in beakers or crucibles: Collaborative study. J. AOAC Int. 85:1217-1240.

Nelson, N. 1944. A photometric adaptation of the Somogyi method for the determination of glucose. J. Biol. Chem. 153:375-380.

Neylon, J. M., and L. Kung Jr.. 2003. Effects of cutting height and maturity on the nutritive value of corn silage for lactating cows. J. Dairy Sci. 86:2163-2169.
NRC. 2001. Nutrient requirements of Dairy Cattle. 7th ed. National Academic Press, Washington, DC.

Phakachoed, N., W. Suksombat, D. Colombatto, and K. A. Beauchemin. 2013. Use of fibrolytic enzymes additives to enhance in vitro ruminal fermentation of corn silage. Livest. Sci. 157:100-112.

Pinos-Rodríguez, J. M., S. S. González, G. D. Mendoza, R. Bárcena, M. A. Cobos, A. Hernández, and M. E. Ortega. 2002. Effect of exogenous fibrolytic enzyme on ruminal fermentation and digestibility of alfalfa and rye-grass hay fed to lambs. J. Anim. Sci. 80:3016-3020.

Playne, M. J., and P. McDonald. 1966. The buffering constituents of herbage and of silage. J. Sci. Food Agric. 17:264-268.

SAS Institute. 2002. SAS software. Version 9.1 ed. SAS Institute Inc., Cary, NC.

Sheperd, A. C., and L. Kung. 1996. An enzyme additive for corn silage: Effects on silage composition and animal performance. J. Dairy Sci. 79:1760-1766.

Spoelstra, S. F., P. G. Van Wikselaar, and B. Harder. 1992. The effects of ensiling whole crop maize with a multi-enzyme preparation on the chemical composition of the resulting silages. J. Sci. Food Agric. 60:223-228.

Stokes, M. R., and J. Chen. 1994. Effects of an enzyme-inoculant mixture on the course of fermentation of corn silage. J. Dairy Sci 77:3401-3409.

Van Soest, P. J. 1994. Nutritional Ecology of the Ruminant. 2nd ed. Cornell University Press, Ithaca, NY.

Woolford, M. K. 1990. The detrimental effects of air on silage. J. Appl. Bacteriol. 68:101-116. 